\title{
NEO-REALISM MEETS THE BLUES IN GHARLES BURNETT'S KILLER OF SHEEP
}

\author{
Keith Mehlinger
}

Morgan State University

"...the very existence of the blues tradition is irrefutable evidence that those who evolved it respond to the vicissitudes of the human condition not with hysterics and desperation, but through the wisdom of poetry informed by pragmatic insight"

(Murray, 1996: 208-209).

Although little known outside of critics' circles and dedicated cineastes, Charles Burnett's Killer of Sheep (1977) "remains to this day a near mythic object, one of the first fifty films inducted into the Library of Congress's National Film Registry" (Foundas, Independent Lens: Charles Burnett, in Kapsis (ed.) 2011:138). The film "tenderly recounts a few days in the life of a slaughterhouse worker, Stan (Henry G. Sanders), whose existence is as bounded by invisible threads of hopelessness as that of the sheep that he is forced to kill each day" (Hozic, The House I live In: An Interview with Charles Burnett, in Kapsis, 2011: 75). During its brief theatrical release in 1977, the New York Times critic Janet Maslin dismissed Killer of Sheep as "amateurish" and 'boring'. Since then, the film has won awards at festivals and "acquired honorary protection by the National Film Registry accorded to a select few 'masterpieces' such as Citizen Kane, and aided its author in winning a prestigious John D. and Catherine T. MacArthur Fellowship", popularly known as the "genius award" (Hozic, 2011: 75). In addition to being selected as one of America's fifty most culturally significant films, the film was named one of the "100 Most Influential Films of All Time" by the National Society of Film and gained critical acclaim in Europe. Burnett told film critic Terrence Rafferty in 2001, "It just takes an extraordinary effort to keep going when everybody's saying to you, ' No one wants to see that kind of movie' or 'there's no black audience" (Kapsis, Interviews: Charles Burnett, 2011: ix). The story of this film's 30-year journey from cult classic to re-release by Milestone Films in theaters and on DVD in 2008 is the story of its music in many ways. To pull together the $\$ 150,000$ for copyright licenses required for the film's re-release, the director Steve Soderbergh "providentially stepped forward with a gift of \$75,000", that enabled Milestone Films, a small distributor, to save the project" (Kehr, Shadow of Watts, in the Light, in Kapsis, 2011: 143).

This article examines core elements of Charles Burnett's film, Killer of Sheep as a "blues 
statement" (Murray, 1996: 208-209) with shared aesthetics of neo-realism and the blues including the visceral power of both modalities, their universal themes of human struggle, and their use of the "objective correlative", or adequate metaphor in the pursuit of truth and consciousness (Murray, 1996: 2). Burnett merges blues as a diviner of truth with a "state of mind" much like that of the Italian neo-realists, which allowed them to "broaden, first of all, the cinema's spiritual horizon", to take moral positions with respect to the social, political, and economic issues facing the nation" (Pacifici, 1962: 241). In the case of Killer of Sheep, Burnett's focus is the black working class of Watts less than a decade after the 1965 riots when over 30 people lost their lives in violence involving the Los Angeles Police Department, the National Guard, and private citizens. Burnett examines present conditions (circa the seventies) and frames circumstances that could easily call for the necessity of action, but like the Italian filmmakers, Burnett makes truth his advocate through cinematic techniques that appear more documentary than narrative, and are in the spirit of what Visconti called an "anthropomorphic cinema", portraying people in their lived environment (Gottlieb, 2004: 35).

Neo-realism meets the blues in Killer of Sheep (1977) as Burnett brings a blues aesthetic to a style of filmmaking "associated with Roberto Rossellini, Luchino Visconti, Vittorio De Sica, and Giuseppe De Santis, among others, working with writers including Cesare Zavattini and Federico Fellini..." (Gottlieb, Rosellini, Open City, and Neorealism, in Gottlieb, 2004: 32). The films deal with the "ravages of fascism" that leave rifts in national identity and that cause the decay of communities. The films show Italians "suffering various forms of material and spiritual poverty and oppression that could not be blamed completely on the Black Shirts and the Nazis" (Gottlieb, 2004: 32). Neo-realism also represents resistance by providing a "continuing critique of the conditions, institutions, and individual predilections that cause violence, poverty, isolation, and spiritual distress" (Gottlieb, 2004: 32).

Of the merged approach that Burnett takes with the blues and neo-realism, it is the blues that is the least understood or valued as a powerful aesthetic envoy that can induce self-reflection, and stir questions of identity with respect to a nation's past and future, as did neo-realism at the end of World War II. Although there is a body of recorded work from the turn of the $20^{\text {th }}$ century forward, the blues was the province of black artists and storytellers. The art form was marginalized because of cultural hegemony, though the blues were foundational to rhythm and blues, and rock music. Burnett, a native of Vicksburg, Mississippi brings his Delta blues values to bear in the film, while coincidentally practicing many of the "Ten Points of Neo-realism", as described by screenwriter Cesare Zavattini in a 1952 film journal that stresses a stripped down cinema vérité emphasizing reality through documentary aesthetics including location production and the use of non-professional actors (Zavattini, Ten Points of Neo-realism,1952: in MacCann, "A Montage of Theories," 1966).

Burnett practices the neorealist aesthetic ever more powerfully because of the blues, for the blues long before the advent of the cinema has been capable of generating cultural selfreflection by embracing humanity (Marsalis, 2008: 61). The blues is music that is older than the European literary movements of the early $20^{\text {th }}$ Century in realism and naturalism that can be traced forward to neo-realism in the cinema (Murray, 1976: 63). As early as 1550, English lexicographers have found records of the phrase "to look blue" meaning "to suffer anxiety, fear, discomfort, and low spirits" (Murray, 1976: 63). The term, "blue devils to designate baleful demons has been traced back as 1616", so it is likely that African-Americans "acquired both the word, and its special connotation" from European Americans (Murray, 1976: 64). 
However blues music has its beginnings in Africa just like the banjo, but was fully evolved in America by slaves expressing their hope, pain, and desires through song that derived from their life experience in a form less choral than spirituals, and not necessarily respectful of the church (Davis, 1995: 36). The blues, like the literary movements from which neo-realism can be traced was concerned with truth and stories of real life. The deep south, especially Mississippi, is where the blues seeped out of swamps and hollers in a character that pilgrims in the 1960s described as "rough, spontaneous, crude and unfinished", dominated by "stark, unrelieved emotion", an intense distillation of the music of slavery, "only a step from the wordless field cries and hollers of an older generation" (Hamilton, 2008: 3-4).

Killer of Sheep, produced in $16 \mathrm{~mm}$ black and white film, in some respects seems an artifact. With its primitive look and feel (adding to its sophistication), unconventional plotting, sparse dialogue, and use of episodic vignettes integrating a soundtrack that is dominantly blues based, I liken the experience of watching this film to that of listening to a vinyl LP with all the pops and scratches in the right places. It is this kind of raw experience that helps to authenticate the pain, the joy, and the sorrow of the blues as an art form less dependent on vocal precision, than on musical precision and nuance that comes as the result of a blues statement (Murray, 1976: 79). Instead of the twelve-measure technicalities of the blues form - the "Holy Trinity" ("three harmonies like the beginning, the middle, and the end of things. Three sung statements and three instrumental responses.) (Marsalis, 2008: 49), I am focused on look and feel of Killer of Sheep as a cinematic incantation of the blues statement to reflect "a sense of life that is affirmative", despite blues lyrics that include, "the absurd, the unfortunate, and the catastrophic", and to "reflect the person making the confrontation, his self-control, his sense of structure and style", and the expression of among other things, "his sense of humor as well as his sense of ambiguity and his sense of possibility" (Murray, 1996: 208-209). These are all issues of portrayal and characterization for the filmmaker, as they are for the blues balladeer (Murray, 1996: 21).

In the case of Killer of Sheep, the soundtrack charts an unusual improvisational course throughout the film as more than accompaniment, but as a character (a balladeer) whose presence imbues the movie with an overall blues feel that underscores the poetic modes of its visual story. The result is a blues nuance that dominates the film despite its soundtrack blending jazz and blues with spiritual and folk music (Paul Robeson), along with R\&B (Earth Wind \& Fire) and classical (including George Gershwin, and Sergei Rachmaninoff). The film and its story have its objective correlative in the blues and Burnett extends cinematic language into the repertoire of the blues where "...the definitive blues statement is not verbal", as words "however well chosen, are secondary to the music" because "what counts for most is not verbal precision (which is not to say vocal precision) but musical precision, or perhaps better still, musical nuance" (Murray, 1976: 79).

As a filmmaker, Burnett's nuance comes through sight and sound, not unlike the purveyor of the blues - the storyteller who conjures a picture through music and verse laced with metaphor. Burnett is the extension of "how the story teller works with language, 'as a 'song and dance man (a maker of molp^es) whose fundamental objectives are extensions of those of the bard, the minstrel, and the ballad maker which, incidentally, are those of the contemporary American blues singer" (Murray, 1996: 21). Ironically, the music that prevented the film's release for 30 years because of copyright issues combines with its mise-en-scene to make one of the most powerful blues evocations ever on screen. David Denby, of the New Yorker, 
was one of the few nationally know film critics to observe that "Burnett used many kinds of African-American music on the soundtrack, and the music itself has the bedraggled eloquence of an old blues record" (Denby, 2007: New York Times). As in most blues music, violence, joy, and pain, hang over Killer of Sheep because of what unfolds due to human circumstances, emotions, and matters of the heart that could at any moment careen to tragic dimensions, or veer toward redemption and the recapitulation of love. The blues is the perfect vehicle for this film because "the blues is full of metaphor in words and music" (Marsalis, 2008: 59). Like the blues, Killer of Sheep is ultimately concerned with "the most fundamental of all existential imperatives: affirmation, which is to say, reaffirmation and continuity in the face of adversity," or like Hamlet, 'to be or not to be,' or to ponder as Burnett's main character does, "whether things are worth all the trouble and struggle" of waking in your bed with the blues all in your head" (Murray, 1976: 6).

Like a musical incantation, the soundtrack interlocking Burnett's story and images provides a feeling of sadness and joy - and most importantly pain, something that the blues knows a lot about (Marsalis, 2008). James Bell writes: "Rarely have songs and images been combined so resonantly and beautifully as in Killer of Sheep whose soundtrack boasts Scott Joplin, Louis Armstrong, and blues singers like Little Walter, Elmore James, Faye Adams, and Dinah Washington". Burnett recalls: "The music was mainly pieces that my mother used to play", that he "decided on them before filming and they helped me to think of certain images for the film. For example Luis Russell's 'Sad Lover Blues' inspired the scene of Stan and his wife dancing through the end. I broke the record so I didn't get to use it, and used Dinah Washington's 'This Bitter Earth' instead" (Bell, Blues People, in Kapsis, 2011: 182).

Killer of Sheep was completed during the so-called blaxploitation period of Hollywood films anointed by a new kind of black cinematic hero in Melvin Van Peebles' independent blockbuster, Sweet Sweetback's Baadasssss Song (1971). Burnett's stark documentary-like approach seems iconoclastic, or an act of resistance given the prevailing Hollywood trends to fund black action films for then growing demand at the box office. Instead, Burnett's film evokes the black and white film work of Roberto Rossellini, Vittorio De Sica and other filmmakers whose work defined Italian neo-realism. The film also bravely stakes rare ground in its realistic portrayal of an African-American working class family trying to "preserve its meaningful relationships and sense of humanity in spite of the pressure and indignities of exploitation" (Klotman, 1991: 1). Berenice Raynaud, the New York correspondent for Cahiers du cinema, pointed out that Killer of Sheep was one of the first films in which European audiences saw a sensitive, un-condescending portrayal of a black family (George, The Long Distance Runner: Charles Burnett's Revolution in Kapsis, 2011: 35). The main characters of the film represent generations of African-Americans who found themselves on the crossroads between urban and rural life in the $20^{\text {th }}$ Century after migration from the south to large cities. It is along these pathways that blues evolved from the delta to cities in the East and in the Midwest. Stan's peril to keep his family out of the clutches of poverty and to be a loving husband and father places his "down home" values in an uncomfortable co-existence with life in Watts (and a new kind of blues). Stan's response is to remain focused, to take a steady course that takes a toll on his psyche and emotional state, but does not deter his affirmation of life in the spirit of Murray's blues statement (Murray, 1996: 208-209). Burnett poetically portrays Stan's blues life by intercutting the ardors of adulthood and toil at the slaughterhouse with "long, real-time master shots of youths playing that suggest their carefree lives while also conveying 
the potential cruelty and danger of their games. Echoing cinema vérité, Burnett often allows the action to unfold in front of the camera, capturing the results on grainy black and white 16 millimeter film; at times the film lumbers along, at other times it slides out to the edge of dissonance" (Kim and Livengood, Talking with Charles Burnett, in Kapsis (editor), 2011: 114).

The film is culled from Burnett's experiences growing up and living in Watts after his family moved there from Mississippi in the late 1940s. In Killer of Sheep, "dusty South Central alleyways evoke the roads of Mississippi, Alabama, Arkansas, which is where most of the neighbors of his youth came from" (Cieutat and Ciment, Interview with Charles Burnett, in Kapsis, 2011: 41). Burnett threads Stan and his family though a series of vignettes suspended between the rituals of childhood and the rigors of adult life. His musical soundtrack forms "the call and response", of a blues incantation that serves as a layer of consciousness for the film. Just as the blues is informed more by its music than lyrics, because even "strong verbal statement can be contradicted and in effect canceled by any musical counterstatement" (Murray, 1976: 82), so too is the result for Burnett's visual story (sad or not) that by virtue of musical counterstatement can bring hope to despair, or reinforce sadness and alienation as portrayed. The result of Burnett's blues counterstatement as a contradiction comes as the result of juxtapositions like "impressionistic fragments from the lives of the working poor against Paul Robeson singing" the uplifting 'What is America to me?' "Renoir-like" humanism through images and sequences that "are the scatterings of joy Burnett finds amid the gray gloom: fleeting moments - a junk strewn lot transformed into a playground by the power of a child's imagination, a husband and wife holding each other in a long-forgotten embrace- that are like mirages in a desert" (Foundas, 2011: 139).

Burnett heard most of the music used in the film "as a kid growing up", and the songs "conjured up images" as he was "thinking of each scene". When it came to Paul Robeson's song - "What is America to me?", Burnett provides a visual contradiction to the "happy life" described that reminded him of a Norman Rockwell painting. Instead, "what you see on the screen is the opposite; Kids living in places where things are torn down, yet still being kids and not really realizing it. It's a contrast between the lyrics and what's going on in the screen. This mean old world comes into play. You see the slaughterhouse and reflect on what's going...I was always interested in showing a slice of life and recording an experience that had a narrative inherent in it." (Gerhard, Charles Burnett Celebrates a Milestone, in Kapsis, 2011: 177). Burnett's visual contradiction to "What Is America to me?" is also his blues counterstatement, for as the filmmaker, he is also the blues balladeer (Murray, 2011: 208-209).

Burnett's portrayal of working class African-Americans remains unique and still garners critical acclaim to this day for there "is nothing else in American movies quite like Killer of Sheep. Thematically the film is a reaction against the blaxpoitation films that were filling downtown theaters in the early seventies. There are no supercops or superpimps in Burnett's Watts..." (Kehr, 2007: 143). Further evidence of Burnett's Hollywood counter-narrative as a blues statement (affirming life) comes from his remapping Watts as more than a physical space, but as a sociological one as well not inhabited "just by pimps, hookers, and OGs (Original Gangsters), but by poverty-line families eking out meager existences while hoping against hope for change to come" (Foundas, 2011: 139).

As the filmmaker of Killer of Sheep in a blues context, Burnet also serves as the balladeer making a blues statement about the nature of joy and pain for children and adults (Murray, 1973: 21-22). As Burnett says, "The very structure of the film comes from this preoccupation: 
how to represent life, the everyday crises" (Arnaud and Lardau, in Kapsis, 2011: 9). The fate of the sheep "is in fact is a metaphor for Stan's own helplessness in the restricted world in which he lives. That impotence has made him withdraw from his family, especially his wife, to whom he denies the affection she craves". At the Toronto Film Festival of Festivals (1981), David Overby called Killer of Sheep "a masterpiece" and "a positive demonstration that there are still filmmakers in the United States who care about film and, more importantly, about people" (Klotman, 1991: 98). Nowhere is this more apparent than how Burnett captures the faces of his characters in rapturous close-ups that tap into consciousness. "The Renaissance painters like Leonardo inserted a glow -Charles Burnett does this when he looks at faces" (George, op. cit. 35). Burnett's kudos are as much for his skills as a filmmaker, as they are for his skills as a balladeer with a commitment to his blues statement (Murray, 1996: 208-209).

The improvised feel of Killer of Sheep adds to its "blues" feel, through a raw cinema vérité and lyrical mise-en-scene that is scripted and storyboarded. There is no mistaking that the film "owes an obvious cinematic debt to Italian neo-realism and documentary, but with an inspired improvisatory feel that's unique in cinema - something closer to the feel of blues or jazz" (Bell, op. cit. 181). Burnett recalls ad-libbing in a few places, but more purposely controlling the film's aesthetic to make it "look like a loosely shot film, where the narrative sort of evolves, but it was scripted. A lot of the images were drawn. I was looking for specific things in the scenes, but the idea was not to have perfect lighting and stuff like that" (Lowery, in Kapsis, 2011: 163).

The primitive look of the film shares a common aesthetic with the classics of neo-realism and their documentary feel, but also produces the cinematic equivalent of a blues statement. Burnett recalls, "I wanted the film to have a rough raw aspect, without light...I wanted the texture to be rough, as if the movie had been made by someone who didn't know how to make movies. I wanted this movie to seem like a work in which the filmmaker didn't try to manipulate things" (Arnaud and Lardau, 1981: 9).

Killer of Sheep takes a decidedly different approach to narrative form than that of Hollywood genre films, and shares aesthetic and narrative characteristics of classic Italian neorealism. Films done after classic period fall into a broader definition of neo-realism as "a cinema of the Resistance, but it is a cinema of resistance interpreted broadly, linked not only specifically to the anti-fascist partisan movement - their practical struggle as well as their utopian dreams - but to a continuing critique of the conditions, institutions, and individual predilections that cause violence, poverty, isolation, and spiritual distress" (Gottlieb, 2004: 32). Killer of Sheep ponders the same issues in a different time and place and represents resistance. Burnett can be further linked to "resistance" by virtue of creating a counternarrative to Hollywood's stereotypes, much like Oscar Micheaux had done a half century earlier in opposition to D.W. Griffith's Birth of a Nation (1915) (Masilela, The Los Angeles School of Black Filmmakers, Chapter 7, Diawara (editor), 1993: 108). Burnett is identified with a group of filmmakers identified by film scholars as the "L.A. School", or alternately the "L.A. Rebellion" including Burnett, Julie Dash, Hailie Gerima, and Billy Woodberry, all UCLA trained filmmakers (Massood, 2003: 107). Burnett recalls at the time that he was just trying to tell the story he wanted on film, as were the others. "But it wasn't a "school" of Black filmmakers, or a conscious effort. Things just happened. Of course, everybody was more or less rebellious at that time" (Reynaud, Burnett, Kapsis, 2011: 57). The student filmmakers "set out to tell stories that rejected Hollywood stereotypes that depicted the black 
community in strictly negative terms - drug infested, violent, malevolent and dysfunctional" (Hozic, 2011: 81).

Although he didn't study neo-realism in film school prior to the genesis of Killer of Sheep in the late 1960s, and "didn't really set out to create a film like the Italians", the look and feel of neo-realism emanates from his artistic choices. His approach was an effort "to try to get at the truth", to confront "the whole issue of Hollywood and the misrepresentation of black people in film — with Gone with the Wind and Stepin Fetchit - well, the idea was to get at the truth of the representation. In that respect, it was neo-realist" (Jones, 2010). This suggests that Burnett's pursuit of truth made him one of the "fragile shoots" of American filmmaking that A.O. Scott finds stronger evidence for in other national cinemas as a "neorealist impulse that proved remarkably mobile and adaptable" long after the end of Italian neo-realism. He includes Killer of Sheep among a handful of American films that "offer not only bracing, poetic views of real life, but also tantalizing glimpses of a cinematic tradition that might have been". As with Burnett's desire to tell a story of the black working class counter to the head winds of exploitive Hollywood trends, Scott suggests that when neo-realism pops up, "it might be though of less a style or genre than as an ethic that finds expression in various places at critical times..." (Scott, New York Times, 2009). Scott has been challenged for the misappropriation of the term "American Neo-realism", by another film critic, Richard Brody, of the New Yorker Magazine (Brody, New Yorker Magazine, 2009). Brody takes exception to Killer of Sheep as an example of "neo neo-realism," taking the position that the neo-realist-like approach was practiced widely to become America's dominant independent film trope in the fifties and sixties (Brody, New Yorker Magazine, 2009). It is my view however, that Burnett forges new ground by combining a blues aesthetic with the instincts and aspirations of neo-realism, and the result seems the "fragile shoot" that A.O. Scott writes about for there are few films that have answered the call of resistance so boldly at a critical moment in history as did Killer of Sheep. With the civil rights movement and the 1965 Watts riots still fresh in his mind, Burnett's gestation and production of Killer of Sheep came at one of those "critical times". Ironically, it was at the same time that the black action film was going strong with films such as Superfly, and Shaft that helped anchor the blaxploitation era of Hollywood films. Burnett's contrary urges merged with his desires for an African-American counter-narrative about the blue-collar people he cared about. His focus on African-Americans in Watts shared thematic fluency with the universal plight of the poor to survive whether in Italy at the end of World War II, or in Los Angeles in the seventies. Though not the site of a declared war, the Watts area of Los Angeles was nevertheless a scarred terrain of urban unrest that pitted African-Americans against police in a racially driven conflict. This landscape of impoverished and working class people provided the backdrop of desolation and poverty for Killer of Sheep, and it would take decades for Los Angeles to recover from riots in the sixties only to be repeated again (most notably) in the nineties following the acquittal of police in the infamous beating of Rodney King.

Burnett's artistic approach to Killer of Sheep was less the pursuit of Roselllini and De Sica, and more the pursuit of truths about the lives of a working class black family in Watts in a period not long after the 1965 Los Angeles riots. It his camera, however, "like that of De Sica and other masters of Italian neo-realism" (that) "captures love for his characters - not because they are good or beautiful but because - they are" (Perez, 1998: 35). From dirt playgrounds to rooftops, to the slaughterhouse and the street, the black and white and silver images of Killer of Sheep play like lyrical moments from a dream that tap into our emotions and spark 
our consciousness. Burnett's camera is part of his "holy trinity" for the blues in the sense that it serves the cycle of verse and instrumentation that is foundational to the blues. Killer of Sheep's most intimate moments are between Stan and his wife and bring to mind classic silent films that Burnett professes an appreciation for in his admiration for Charlie Chaplin and Buster Keaton (Burnett and Lane, One on One: Charles Burnett and Charles Lane, in Kapsis, 2011: 66). As a skillful filmmaker, Burnett "is able to render the mundane lyrically: the little details move us. The camera on its own -separate from the narrative and the powerful music- is damp with meaning. In Killer of Sheep there are haunting shots of Judas goats at the head of a ramp, below them the dumb, sweet faces of future lamb chops now hesitant, now gullible, finally carcasses and parts lining the walls of the Solano Meat Company" (Kennedy, The Black Familiar, Kapsis, 2011: 40). He draws metaphorical connections without being "selfpitying" between the helplessness of sheep, their inevitable march to the killing room, and the trapped quality of Stan's existence leading to his insomnia and insular sadness. Killer of Sheep is a blues manifestation as much for its music, as for its images and their aesthetic look and feel that confirms that neo-realism shares the instincts of Murray's blues statement for "a sense of life that is affirmative" despite struggle and tragedy as obstacles to human dignity. This blues sentiment is shared in films such as Paison, Open City, Bicycle Thief, and Umberto $D$, all classics of Italian neo-realism with the blues at their core.

Hopes and dreams are frequently dashed in the blues or remain just out of reach, and Killer of Sheep is no exception. Even when Stan and his friends plan an escape to the horse races, "their spare less car blows a tire", and they return home on a steel rim without ever having reached their destination. When Stan's friend, Eugene (Eugene Cherry) buys a car engine with all the money he has plus the shirt off his back, we see the two men struggle precariously to move the hunk of metal down multiple levels of steps, to then finally heft it onto a truck and drive off only to have it slide out and crack on the street. Each vignette is its own blues. "The audience empathizes with the character's frustration, and even sees ironic humor in it, but always senses a keen and sympathetic, un-condescending presence behind the camera. But this is not a film that discards the care of its characters because of their plight, nor does it deny them loving moments with their families, or meaningful friendships because of exploitation" (Klotman, 1991: 97). As Wynton Marsalis reminds us: "Sad or funny, factual or fantasized, raunchy, majestic, or even maudlin, the blues reassures us with the unpredictable inevitability of life itself. Bad as things may be, they will get better or they could have been worse, and no times are so bad they can't be turned into good times" (Marsalis, 2008: 52-53).

Burnett the filmmaker -the blues balladeer puts lives in motion like fragmented lyrics to a soundtrack that serves as reinforcement or counterstatement to vignettes that unfold around Stan and his family. As a skillful storyteller he makes us worry for his people, and care about them despite denying us absolute resolution in the way of a Hollywood ending. What holds firm throughout Stan's travails is the "warmth and tenderness" of his family, but "especially his wife". Stan will return to work and move in a direction to repair his relationship with his wife, but things are left largely unresolved as in real life (Masilela, 1993: 112). We will not have the satisfaction of finding out if Stan can guide and protect his strong-willed teenage son from the streets, or shield his daughter from her fears for her father's and mother's estrangement. But these are the universal problems that families live with and there is hope in the spirit of the blues statement when a shy handicapped girl (obviously incapable of being prepared for motherhood) reveals she is pregnant and is embraced and supported by Stan's wife and other 
women. The nature of the blues is to seed hope and Burnett despite "the powerful undercurrent of fatigue and despair" in the film provides the blues counterstatement as "an odd buoyancy", that recognizes that "although the people are poor, they haven't, most of them, altogether stopped living: The grown-ups get by somehow or other, and the kids find ways to play". Burnett, like the blues balladeer, provides the integrity of a blues statement that is more than "a drab, grinding chronicle of misery," because we can still sense Stan's affirmation of life through his loving moments with his wife and daughter, and through his friendships (Rafferty, Invisible Man, in Kapsis, 2011: 120).

At dusk in the dusty playgrounds of undeveloped spaces in Killer of Sheep, the apparent ringleader of a group of boys tries to entice the others to visit the "Vicksburg", to watch the pimps and prostitutes. No doubt this is Burnett's nod to his birthplace, and to the Mississippi Delta, arguably the home of the blues. Though Burnett intends no meeting (or blending) of neo-realism and blues, it is inevitable. As Burnett reminds us, "I was raised with music, with blues". He recalls his mother's record collection that included "a lot of blues records that he was constantly playing and replaying. At that time rock ' $n$ ' roll was our big thing. In people's minds at the time, the blues were linked to alcohol, but I felt like I was forced to listen". The indelible impact of the blues leaves its mark on his search for truth in Killer of Sheep and on other of his major works, including To Sleep With Anger, which is consistent with his explorations of "the South's enduring and complex legacy in the American consciousness" (Bell, 2011: 183).

When looking at Killer of Sheep in terms of its "objective correlative" or metaphorical debt to the blues, one must consider its combination of mise-en-scene, narrative form, pacing, characterization, dialogue, and of course music. In other words, the aggregate disposition of the elements that comprise the film and inform the film through its author's point-of-view have the "blues" on their mind or as a reference point. Burnett recalls, "it was only much later that I could listen to those blues records and discover that I loved the blues without knowing it, that I needed it. And when I made Killer of Sheep I wanted to preserve those old records that no one listened to anymore and put them in the movie" (Cieutat and Ciment, 2011: 50).

Burnett as a balladeer delivers a cinematic blues statement that provides "an indefinable poetry to many of the film's images, which display flashes of humor and beauty, underpinned by a deep sense of melancholy - much like the blues" (Bell, 2011: 182). Images and music in the film serve as blues counterstatements that reinforce irony as a community on the margins of society goes about their lives to strains of orchestral music by Rachmaninoff, Gershwin, and the rollicking African-American Symphony by William Grant Still. From the majestic voice of Paul Robeson to the raw blues of Lowell Fulson, the soundtrack for Killer of Sheep expresses and complements the themes of the film and in its totality plays the role of a character in affirming this film's blues statement. This character knows the swamps and hollers, the juke joints, the country sermon, and the devil of a price to seek a better life in the city where promise brings peril to the family and the community at the cost of human dignity. This is the blues! And powerful things happen when neo-realism meets the blues to aesthetically share an objective correlative as is evidenced by the visceral power, consciousness, and nuance of Killer of Sheep.

"With the blues you have layers of meaning. The words say one thing, the way they're sung can say another, and the music always says something else. For all of the sorrow of some blues lyrics, the music is always grooving; a groove implies dance, and dance always brings 
joy. Dizzy Gillespie said it best: 'Dancing never made nobody cry.' That's the key to understanding the blues. The blues delivers both joy and sorrow" (Marsalis, 2008).

\section{BIBLIOGRAPHY}

BRODY, Richard (2009), About Neo-Neo Realism - The Front Row - New Yorker Online Only http://www.newyorker.com/online/blogs/movies/2009/03/in-re-neoneorea.html (2009, March, 20)

DAVIS, Francis (1995), The History of the Blues, New York, Hyperion.

DIAWARA, Manthia (ed.) (1993), Black American Cinema, New York, Routledge.

DENBY, David (2007), "Watts Happening", The New Yorker, (2007, April 2).

GOTTLIEB, Sidney (2004), "Rossellini, Open City, and Neorealism", Roberto Rossellini's Rome Open City, Cambridge, Cambridge UP.

HAMILTON, Maybeth (2008), In Search of the Blues, New York, Basic Books.

Jones, James, River Film Society - An Interview with Charles Burnett by Michael Jones - Parrish, 2010.

KAPSIS, Robert (2011), Charles Burnett: Interviews - Conversations with Filmmakers Series, Peary, Gerald, General Editor, Mississippi/Jackson UP.

KLOTMAN, Phyllis Rauch (1991), Screenplays of the African American Experience, Bloomington and Indianapolis, Indiana UP.

MARSALIS, Wynton with Ward, Geoffrey C. (2009), Moving to Higher Ground: How Jazz Can Change Your Life, New York, Random House.

MASSOOD, Paula J. (2003), Black City Cinema - African American Urban Experiences in Film, Philadelphia, Temple University Press.

MURRAY, Albert (1995), The Hero and the Blues, New York, Random House.

- (1976), Stomping the Blues, Cambridge, Da Capo Press.

- (1996), The Blue Devils of Nada: A Contemporary American Approach To Aesthetic Statement, New York, Pantheon Books.

NELSON, Kim (2003), Senses of Cinema, www.sensesofcinema.com, Issue 26.

PACIFICl, Sergio (1962), A Guide to Contemporary Italian Literature, From Futurism to Neorealism, Cleveland \& New York, Meridian Books.

PEREZ, Gilberto (1998), The Material Ghost, Baltimore \& London, The Johns Hopkins UP.

REID, Mark A. (2005), Black Lenses, Black Voices: African American Film Now, Lanham, Rowman \& Littlefield Publishers.

AA. VV. (2003), "The Blues: Warming by the Devil's Fire: Director Interview with Charles Burnett, www.pbs.org/theblues/aboutfilms/burnettinterview.html, Vulcan Productions, Inc.

ZAVATTINI, Cesare (1966), "Some Ideas on the Cinema", in MacCann, Richard Dyer (1966) Film: A Montage of Theories, New York, E.P. Sutton. 